\title{
DEPRESSION AND MIGRAINE
}

\author{
José Carlos Busto Galego', José Paulo Cipullo², \\ José Antonio Cordeiro ${ }^{3}$, Waldir Antonio Tognola ${ }^{3}$
}

\begin{abstract}
The objective of this study was to evaluate both the presence and intensity of depressive symptoms in patients with episodic migraine (EM) and transformed migraine (TM) or chronic migraine, comparing them with a control group. Beck Depression Inventory (BDI) was used for this purpose. The median of BDI score of the control group was significantly lower than the EM and TM groups $(p<0.0005)$. Either the EM or the TM did not show any significant difference in relation to the median of BDI scores $(p=0.12)$. The TM group showed a higher frequency of severe depression when analyzed qualitatively by dependence analysis. Symptoms of severe depression by means of qualitative analysis may strengthen a co-morbidity between depression and transformed migraine. This association might be considered rather a factor of TM perpetuation than a risk factor for the transformation of EM into TM.
\end{abstract}

KEY WORDS: transformed migraine, chronic migraine, migraine, depression, Beck Depression Inventory.

\begin{abstract}
Depressão e migrânea
RESUMO - O objetivo deste estudo foi avaliar a presença e a intensidade de sintomas depressivos entre pacientes com migrânea episódica (ME) e migrânea transformada (MT) ou migrânea crônica, comparando-os com um grupo controle. O Inventário de Depressão de Beck (IDB) foi aplicado para esta finalidade. A mediana das pontuações do IDB do grupo controle foi significantemente menor que a dos grupos ME e MT $(p<0,0005)$. Os grupos ME e MT não apresentaram diferenças significantes em suas medianas das pontuações $(p=0,12)$. Quando avaliados de forma qualitativa, pela análise de dependência, o grupo MT apresentou freqüência maior de depressão severa. Sintomatologia depressiva mais severa do ponto de vista qualitativo poderia reforçar possível co-morbidade entre depressão e migrânea transformada. Esta associação poderia ser considerada mais como um fator de perpetuação da MT do que um fator de risco de transformação da ME para a MT.
\end{abstract}

PALAVRAS-CHAVE: migrânea transformada, migrânea crônica, migrânea, Inventário de Depressão de Beck.

Several epidemiological and prospective studies have reported an association between migraine and depression ${ }^{1-6}$. Breslau et al. ${ }^{4}$, using longitudinal data, examined the association between migraine and major depression in a sample of 1,007 young adults (21-30 years of age). These authors concluded that association might result from bi-directional influences; that is, each disorder increased the risk for first onset of the other. It remains unclear if common etiological factors might share migraine and depression pathophisiology, although some findings strengthen this hypothesis ${ }^{7,8}$. Episodic migraine (EM) may evolve to a daily-type headache known as transformed migraine ${ }^{9}$ (TM) or chronic migraine. The term chronic migraine was recently introduced in the classification review of International Headache Society ${ }^{10}$. The reason for the increase of frequency in the migraine attacks, trans- forming than into daily headache is little known. Excessive use of analgesics and ergotamine compounds; stress situation in the family or at work; traumatic life events; hypertension, birth control pills; abnormal personality profile and co-morbidity with some disorders such as anxiety and depression are factors linked with this transformation ${ }^{11}$. Galego et al. ${ }^{12}$, based on clinical and demographic characteristics of episodic and transformed migraine, observed that earlier beginning of attacks might be a risk factor for transformed migraine. Taking into account the co-morbidity between migraine and depression, it is important for clinical practice to evaluate depressive symptoms as well as how their intensity is developed in patients with EM and TM. Few comparative studies have examined the intensity of how the depressive symptoms affect these two groups ${ }^{13}$.

Departamento de Ciências Neurológicas da Faculdade de Medicina de São José do Rio Preto (FAMERP), São José do Rio Preto SP, Brasil: ${ }^{1}$ Professor Assistente Mestre; ${ }^{2}$ Professor Adjunto Doutor; ${ }^{3}$ Professor Adjunto Livre Docente.

Received 26 December 2003, received in final form 25 March 2004. Accepted 15 May 2004.

Dr. José Carlos Busto Galego - Rua Prof. Nelson I. Bento Lutaif 145 - 15091-550 São José do Rio Preto SP-Brasil. E-mail: jcgalego@uol.com.br 
This study aimed at evaluating both the presence and intensity of depressive symptoms among patients with EM and TM, comparing them with a control group.

\section{METHOD}

A sample of 80 patients, both genders, ages ranging from 18 to 60 years, were examined at the headache outpatient service of Hospital de Base, Medical School of São José do Rio Preto, SP. In this clinical prospective study, the patients were consecutively admitted and divided into two groups. The first group comprised $40 \mathrm{pa}-$ tients with the EM diagnosis, according to the International Headache Society's criteria ${ }^{14}$. The second group, 40 patients with TM or chronic migraine diagnosis, according to Silbertein et al. criteria ${ }^{15}$. A control group of 40 patients (without migraine or chronic headache) was selected among patients from the gynecological and clinical outpatient services of this hospital. Patients with some chronic diseases were not admitted in the study. A psychologist evaluated the presence of some depressive symptoms by means of Beck Depression Inventory ${ }^{16}$ (BDI). The BDI is a 21-item inventory developed to measure the extend of an individual's depressive symptoms. Tests of Variance Analysis, Kruskal-Wallis and Dependence Analysis ${ }^{17}$ were used for statistical analysis. The Ethics Research Committee of Medical School of São José do Rio Preto, SP, approved this study.

\section{RESULTS}

The EM group comprised 33 females $(82.5 \%)$ and 7 males $(17.5 \%)$; the TM, 38 females $(95 \%)$ and 2 males (5\%). The control group comprised 37 females (92.5) and 3 males (7.5\%). At the first evaluation, evidence of different mean ages was not observed among the three groups $(p=0.95)$ (Variance Analysis, Table 1). Table 2 shows the BDI scores of the EM, $\mathrm{TM}$ and control groups. There were significant differences among the medians of BDI scores of the three groups ( $p<0.05$, Kruskal-Wallis test). The medi-

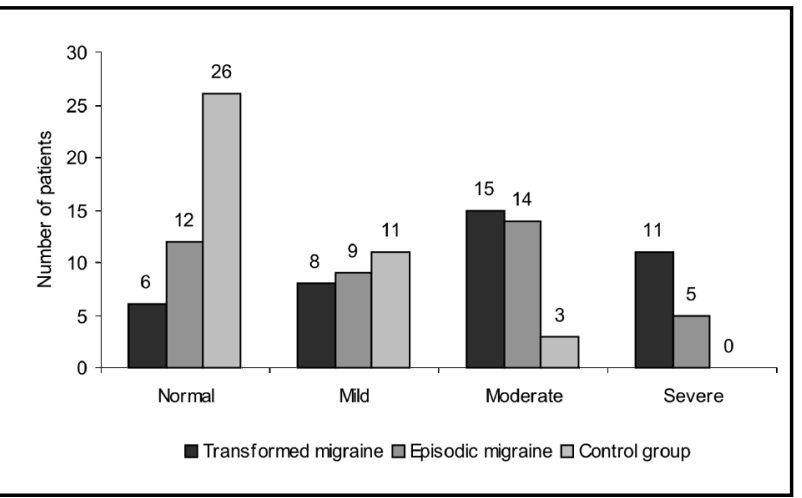

Fig 1. Level of depression measured by Beck Depression Inventory.

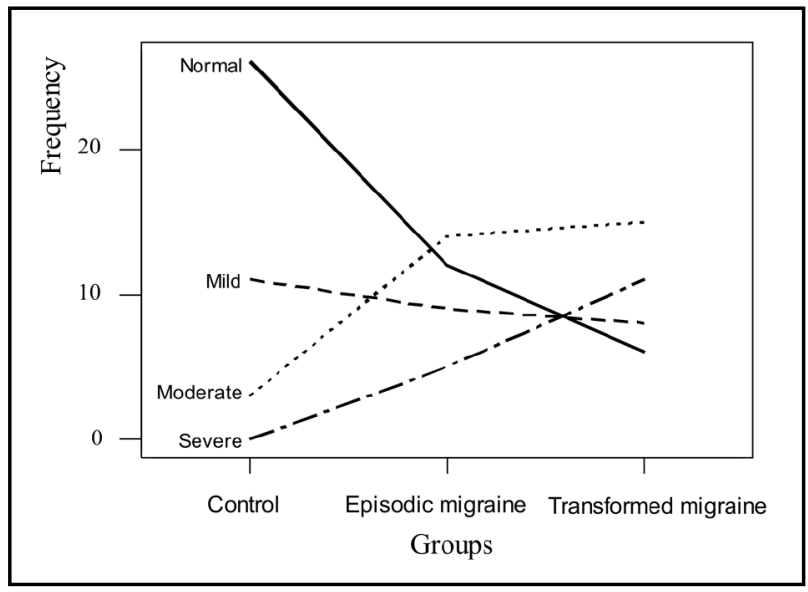

Fig 2. Frequency profile of depression according to the groups.

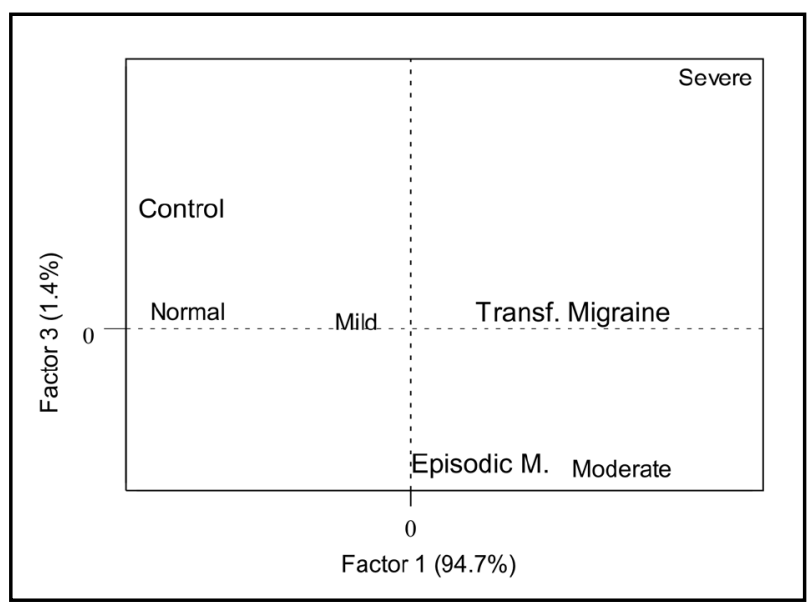

Fig 3. Dependence Analysis - Migraine and Depression

an of the control group was significantly lower than the EM and TM groups ( $p=0.05)$. According to the BDI scores, the patients' depression of the EM, $\mathrm{TM}$ and the control group was classified as: normal, mild, moderate and severe (Fig 1). As shown in Figure 2 , the normal pattern (descending curve) is correlated with the control group, while the severe (ascending curve) with transformed migraine. When analyzed qualitatively (Dependence Analysis), the patients with TM showed a higher association of severe depression, while the patients with EM showed higher frequency and association of moderate depression (Fig 3).

\section{DISCUSSION}

TM is the most common type of chronic daily headache $(\mathrm{CDH})^{18-21}$. Taking into account that patients with $\mathrm{EM}$ may evolve into $\mathrm{TM}^{9}{ }^{9}$, it is important to recognize this transformation process. Analgesic overuse $^{11,22}$ and depression co-morbidity ${ }^{11,13}$ are 
Table 1. Age of the three groups at first examination.

\begin{tabular}{lccc}
\hline Statistic & Episodic migraine & Transformed migraine & Control group \\
\hline Mean (SD) & $37.3(10.3)$ & $37.1(11.7)$ & $36.8(11.5)$ \\
Median & 35.5 & 34 & 34 \\
Range & $18-55$ & $19-59$ & $18-59$ \\
\hline
\end{tabular}

$\mathrm{SD}$, Standard deviation; values in years.

Table 2. Beck Depression Inventory scores.

\begin{tabular}{lccc}
\hline Statistic & Episodic migraine & Transformed migraine & Control group \\
\hline Mean (SD) & $17.5(10.7)$ & $21.3(10.9)$ & $6.9(6.0)$ \\
Median & 16 & 21 & 5.5 \\
Range & $0-51$ & $2-44$ & $0-22$ \\
\hline
\end{tabular}

SD, standard deviation; values in years.

factors, which may be associated with the transformation of EM into TM. The objective of this study was to evaluate both the presence and intensity of depressive symptoms among patients with EM and TM, comparing them with a control group (without migraine). The BDI has been intensively validated, and it was the instrument used for this evaluation. The BDI was not developed for depression diagnosis, but as an instrument for quantifying and qualifying depressive symptoms at the time of the evaluation ${ }^{16}$. Patients with chronic diseases were not admitted in the selection of the three groups, since this might produce a bias in the interpretation of depressive symptoms.

The results showed that the depressive symptoms were more common in TM and EM when compared to the control group. Several studies have reported an association between migraine and depression, although their patholophysiogical mechanism as well as their concomitance is still an issue of discussion in the literature ${ }^{1,4,7,8,23-25}$.

Patients with EM and TM did not show significant difference in the BDI scores; however there was a qualitative tendency for more severe depression levels in the TM group.Magnusson and Becker $^{13}$, applying the BDI in 50 patients with EM and 37 with TM, did not find significant difference in the scores of both groups, however they pointed out that $29.7 \%$ of the patients with TM presented a higher percentage of a moderately severe depression compared with only $18 \%$ of the patients with EM. Based on these results, the authors have suggested that the greater level of depression ob- served in the TM group might strengthen Mathew at al. hypothesis ${ }^{9}$, that is, the depression might be a factor for the transformation of EM into $\mathrm{CDH}$.

In the present study, both the EM and TM groups have presented depression. However, a more expressive depression, according to qualitative evaluation, occurred in the TM group. In TM, the presence of depressive symptoms qualitatively more severe might suggest a greater co-morbidity with depression. Another possible suggestion is that this association performs as a factor of perpetuation of TM, rather than a factor for transformation. The measure of depressive symptoms in patients with EM or TM by means of the BDI provides the clinician an effective subsidy in relation to the best decision for the therapeutic procedure.

In conclusion, patients with TM have presented depressive symptoms more severe according to qualitative analysis, strengthening some comorbidity with depression. This qualitative association with severe depression might be considered rather a factor of TM perpetuation than a risk factor for the transformation of EM into TM.

Acknowledgements - We are grateful to Adília M. Pires Sciarra for the help in the English version.

\section{REFERENCES}

1. Merikangas KR, Merikangas JR, Angst J. Headaches syndromes and psychiatric disorders: association and familial transmission. J Psychiat Res 1993;27:197-210.

2. Breslau N, Merikangas K, Bowden CL. Comorbidity of migraine and major affective disorder. Neurology 1994;44 (Suppl. 7):17-S22.

3. Merikangas KR, Stevens DE, Angst J. Psychopathology and headache syndromes in the community. Headache 1994;34:17-26. 
4. Breslau N, Davis GC, Schultz LR, Peterson EL. Migraine and major depression: a longitudinal study. Headache 1994;34:387-393.

5. Breslau N, Andreski P. Migraine, personality and psychiatric comorbidity. Headache 1995;35:382-386.

6. Breslau N. Psychiatry comorbidity in migraine. Cephalalgia 1998;18 (Suppl. 22):S56-S61.

7. Cox D, Thomas D Relationship between headaches and depression. Headache 1981;21:261-263.

8. Garvey MJ, Tollefson GD, Schaffer CB. Migraine headaches and depression. Psychiatry 1984;141:986-988.

9. Mathew NT, Reuveni U, Perez F. Transformed or evolutive migraine. Headache 1987;27:102-106.

10. Headache Classification Committee of The International Headache Society. The international classification of headache disorders, $2^{\text {nd }}$ ed Cephalalgia 2004;24 (Suppl. 1):S1-S160.

11. Mathew NT, Stubits E, Nigam MR Transformation of episodic migraine into daily headache: analysis of factors. Headache 1982;22:66-68.

12. Galego JC, Cipullo JP, Cordeiro JA, Tognola WA. Clinical features of episodic migraine and transformed migraine: a comparative study. Arq Neuropsiquiatr. 2002;60:912-916.

13. Magnusson JE, Becker WJ. A comparison of disability and psychological factors in migraine and transformed migraine. Cephalalgia 2002;22:172-178.

14. Headache Classification Committee of the International Headache Society. Classification and diagnostic criteria for headache disorders, cranial neuralgias and facial pain. Cephalalgia 1988;8 (Suppl. 7):S1-S96.
15. Silberstein SD, Lipton RB, Solomon S, Mathew NT. Classification of daily and near-daily headaches: proposed revisions to the IHS criteria. Headache 1994;34:1-7.

16. Beck AT. Beck Depression Inventory. San Antonio, Texas: Harcourt Brace, The Psychology Corporation, 1993.

17. Cordeiro JA. Análise de dependência. Tese, UNESP. São José do Rio Preto; 1990.

18. Solomon S, Lipton RB, Newman LC. Clinical features of chronic daily headache. Headache 1992;32: 325-329.

19. Manzoni GC, Micieli G, Granella F, Martignoni E, Malferrari G, Nappi G. Daily chronic headache: classification and clinical features. Observation on 250 patients. Cephalalgia 1987;7 (Suppl 6):S169-S170.

20. Manzoni GC, Sandrini G, Zanferrari C, Verri AP, Franco Granella F, Giuseppe Nappi G. Clinical features of daily chronic headache and its different subtypes. Cephalalgia 1991;11(Suppl 11):S292-S293.

21. Jevoux Cda, Moreira PF Filho, Souza JA. Primary chronic daily headache: a report on 52 cases. Arq Neuropsiquiatr 1998;56:69-70.

22. Mathew NT, Kurman R, Perez F. Drug induced refractory headache: clinical features and management. Headache 1990;30:634-638.

23. Couch JR M, Ziegler DK, Hassanein RS. Evaluation of the relationship between migraine headache and depression. Headache 1975;15:41-50.

24. Holm JE, Penzien DB, Holroyd KA, Brown TA. Headache and depression: confounding effects of transdiagnostic symptoms. Headache 1994;34:418-423.

25. Breslau N, Lipton RB, Stewart WF,Schultz LR, Welch KM. Comorbidity of migraine and depression: investigating potential etiology and prognosis. Neurology 2003;60:1308-1312. 